\title{
Peertechz
}

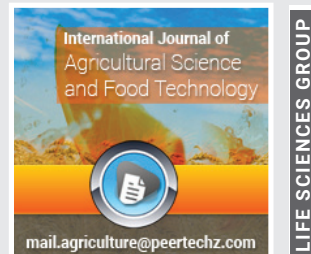

Review Article

\section{Application of Genetically Modified Organism (GMO) crop technology and its implications in modern agriculture}

\section{Werkissa Yali*}

Ethiopian Institute of Agricultural Research, Chiro National Sorghum Research and Training Center, P.O.BOX 190, Chiro, Ethiopia

Received: 13 December, 2021

Accepted: 07 January, 2022

Published: 08 January, 2022

*Corresponding author: Werkissa Yali, Ethiopian Institute of Agricultural Research, Chiro National Sorghum Research and Training Center, P.O.BOX 190, Chiro, Ethiopia,Email: workissayali@gmail.com

Keywords: GMO; Genetic engineering; Plants; Organisms

Copyright License: @ 2022 Yali W. This is an openaccess article distributed under the terms of the Creative Commons Attribution License, which permits unrestricted use, distribution, and reproduction in any medium, provided the original author and source are credited.

https://www.peertechzpublications.com

\section{Abstract}

Genetic modification entails incorporating DNA into an organism's genome as well as putting new DNA into plant cells in order to create a genetically modified plant. Chemicals are poured into plants to improve product sizes and productivity in genetically modified organisms (GMOs), a type of clinical farming. The goal of genetic modification is to provide enhanced features to plants by altering their genetic makeup. This is done by inserting a novel gene or gene into the genome of a plant. Flavr Savr tomatoes were the first genetically modified plants, and they were modified to delay the ripening process, preventing tenderness and rot. Complete crop production increased significantly after the introduction of GM crops at some point during the generation; some of these increases may be due to GM technologies and crop protection advances that have been made possible, despite the fact that GM crops adopted so far are not crop yields. GMOs gain humanity when they are utilized for purposes like improving the availability and quality of food and hospital therapy, as well as contributing to a cleaner environment. If employed correctly, they have the potential to improve the economy without inflicting more harm than good, as well as gain from its ability to alleviate hunger and sickness around the world. However, the full potential of GMOs cannot be identified without thorough research and attention to the dangers associated with each new GMO on a particular scenario basis. Improved resistance to disease and pests can be achieved by genetic modification. It may enable the production of more nutritious staple plants that provide key micronutrients that are frequently lacking in the diets of poor people. As a result, the purpose of this review was to assess the deployment of genetically engineered crops and their effects on modern agriculture progress.

\section{Introduction}

GMOs (genetically modified organisms) are organisms whose genetic fabric (DNA) has been altered in a way that prevents it from occurring naturally through mating or recombination [1]. The word "genetic alteration" refers to the process of altering an organism's genetic makeup by introducing specific beneficial genes [2]. The genetic material of a genetically modified creature has been altered using genetic engineering techniques (GMO). Genetic engineering processes are usually based on knowledge gained from microbiological research or genetics, and they allow for oneof-a-kind interventions into the genotypes of individuals, living organisms, and viral genomes [3].

"A genetically modified organism and what constitutes genetic engineering are defined differently, but the most common definition is an organism that "does not originate spontaneously through mating and/or natural recombination". Genetically modified (GM) organisms include everything from animals to flowers to microorganisms." Genetics are programmed into species, to all species (to create mutations) even within kingdoms. Endogenous genes may be amplified, modified, or deleted, or inserted in a novel gene [4].

A DNA sequence that gives information about whether or not a particular feature/trait gene exists. DNA is found in all living things (genes). Chromosomes are where genes are found. Genes are heredity items that can be passed down from generation to generation and offer instructions for the organism's growth and function. Plants that have undergone genetic alteration are referred to as Genetically Modified (GM) crops, transgenic plants, or Genetically Engineered (GE) vegetation [5]. It is considered genetic engineering when an 
organism is modified using procedures that allow for direct mutation or removal of genes from that organism. The phrases recombinant DNA and rDNA strategies refer to the same thing.

For many years, humans have been modifying the DNA of plants by adopting a gradual approach to plant breeding. In recent years, scientists have been able to alter flowers more quickly by changing their DNA in a lab setting [6]. Traditionally, plant breeders have created new varieties of plants by selecting and crossbreeding flowers with qualities that the plant breeders want in the crop. The plant breeder uses this strategy to select which blooms to go and thus change the genetics of the crop's future technology by relying on visible qualities inside the flowers. As a result of the fact that this method does not always or consistently provide the desired effects, new plant styles may take 15 or more years to emerge [7].

GMOs, or genetically modified plants, are genetically modified or genetically modified plants, such as inbreeding/ reproduction and/or DNA replication [8]. Single genes can be transferred from one organism of a species to all other organisms of that same species, or genes can be switched between unrelated species, depending on the technique used to create GMOs. GMO production is a difficult scientific procedure that costs a lot of money and necessitates extensive testing before a crop is released for commercial production [9].

It is not without dispute that genetically modified crops are used to alleviate poverty and solve food security challenges. Officials in developing nations, on the other hand, have looked into genetically modified plants as a potential tool for increasing food yield (Aerni, 2005). However, disagreements about their benefits and reservations about their application have hampered their implementation (Aerni and Bernauer, 2006; Kikulwe, et al. 2011). A review of the safety of genetically modified crops for consumers, farmers, and the environment has spurred their usage. This idea is described in the context of biosafety, which is defined as the precautions employed in the cultivation and distribution of genetically modified plants and products (Prakash, et al. 2011).

Many debates and (bad) sentiments have accompanied the growth, use, and commercialization of genetically modified crops around the world, even from clients (Kikulwe, et al. 2011). These beliefs are influenced by a lack of understanding of the clinical concepts underpinning gene modification technology, a lack of recognized capacity benefits of GMOs, non-secular, moral, or ethical ideals, and an inability to accurately define what constitutes a GMO (Pino, et al. 2016). However, because the clientele represents a potential quitter, it is necessary to assess their readiness for the adoption of GM crops. It's also crucial to figure out what the difficulties' expectations and perspectives are. Generally, the goal of this review would be to evaluate the use of genetically modified agricultural technology and its consequences for current agricultural development.

\section{Literature review}

History of genetically modified organism: The use of genetically modified organisms, or GMOs, in agriculture began long before recorded history. For up to 10,000 years, prehistoric farmers chose the most effective vegetation and seeds from their tamed plants [10]. In 1972, Stanley Cohen and Herbert Boyer devised technologies that allowed them to chemically reduce and splice DNA strands at certain points in the collection. Boyer used an enzyme to decrease the coding for a specific protein and fix it to different DNA. Cohen also devised a method for introducing these DNA sequences into the cells of microorganisms, including yeast. These bacteria were transformed into hormone producers by the two scientists working together [11]. They established Genentech in 1976 and introduced human genes that make insulin into strains of microorganisms. Those microorganisms started making insulin. They then created human growth hormone. HGH is now being utilized to help dwarf children grow to their full height. Human cadavers were the most convenient supply of the medication prior to genetic alteration procedures [12].

Since 1995, rennet obtained from genetically modified organisms has been utilized in the production of 67 percent of American cheese [13]. In 1994, Monsanto released a synthetic version of bovine growth hormone (BGH) that had been genetically engineered. To improve milk output, farmers may inject the hormone all at once into dairy cows. The hormones were feared to poison the milk supply and harm the animals, according to critics. However, BGH is widely used by the general public and farmers for the most part [14].

From bacteria with weak cell walls to plants with thick, solid cell walls, Bt plants were the next stage in the evolution of living organisms. According to agronomists at the University of Washington in 1976, a small, circular DNA molecule called plasmid may want to attach itself to the nucleus of a plant cell and cause serious illness. They had identified a form of gene splicing that was fundamentally natural [15].

Plant cell walls have also been made permeable using enzymes. In 1983, scientists from two universities and Monsanto discovered how to delete harmful genes from plasmids, insert the desired gene, and get the plasmid into the plant cell, where it could be delivered into the nucleus [16]. These techniques paved the way for genetic engineering, which led to the development of Bt, Roundup-ready, and other genetically modified plants, which will be discussed in the next article.

Genetically Modified (GM) ingredients were first permitted for human consumption in the United States in 1994, and by $2014-15$, nearly $90 \%$ of corn, cotton, and soybeans planted in the US were GM [17]. GM plants already span nearly 1.8 million square kilometers $(695,000$ square miles) of land in more than a dozen nations around the world, thanks to the 2014 deal. The Americas are home to the bulk of genetically modified plants.

Engineered vegetation can greatly increase agricultural yields while reducing the use of chemical insecticides in particular circumstances [18]. The use of broad-spectrum pesticides has decreased in many areas where plant life is being developed, such as potatoes, cotton, and corn, which have been gifted with a gene from the bacterium Bt, which creates a natural insecticide known as Bt toxin. In India, subject studies 
comparing Bt cotton to non-Bt cotton revealed that the GM crop increased yields by 30-80 percent [19]. This rise was attributed to a significant improvement in the GM plant's ability to combat bollworm infestations, which had previously been prevalent. Studies of Bt cotton farming in Arizona, United States, found only minor gains in yield of about $5 \%$, with an estimated fee reduction of $\$ 25-\$ 65$ (USD) per acre attributed to fewer pesticide packages. In China, where farmers were granted access to Bt cotton for the first time in 1997, the GM crop proved to be a success. Farmers who planted Bt cotton used 50-80\% fewer pesticides while increasing their income by up to 36 percent.

\section{To make a GMO plant, follow these simple steps}

Making a GMO plant is a complicated procedure, but it follows these simple steps.

Identifying gene (s) of interest: To create a GMO plant, scientists must first determine which traits are required, such as drought resistance, herbicide resistance, or pest resistance. Then they look for an organism (plant, animal, or microbe) with that attribute already encoded in its genes. Typically, the gene of interest will already be available as a part of a "library" of small chunks of the donor pressure or species' whole genome [20]. The gene(s) responsible for an organism's desired characteristics, such as drought tolerance or insect resistance, are identified using available knowledge about the structure, function, or region on chromosomes. If this is the case, the gene will be multiplied using a PCR reaction. If, on the other hand, the gene has to be extracted from a genome that has never been studied before, a more sophisticated procedure must be followed.

The use of the Polymerase Chain Reaction (PCR) technology allows the gene in each of the aforementioned instances to be enlarged to the level of several million copies required for the assembly era [21]. The hobby gene's properties, as well as other useful sequences like promoters, are sent by the developer to regulators. This comprises gene and product features in the donor organism, as well as the intended trait in the recipient organism, to aid regulators in spotting potential harmful consequences before experiments are completed [22].

Cloning the gene of interest (plant transformation and insertion of gene(s) into a transfer vector): The desired gene is inserted in a "construct" after numerous copies have been created. After the hobby gene has been ligated into the assembly enzymatically, the complete complex is ligated into bacterial plasmids, which operate as "manufacturing vectors" and allow the gene to be duplicated often within the bacterial cells [23]. After that, the bacteria are plated out. It is possible to tell whether the vector has been taken up by the bacterial cells using reporter genes. This usually entails a few color trades within the colonies with introduced DNA. After the plasmids have been removed from the bacterial cells, the typically amplified DNA construct is enzymatically cut out, and it is ready to be inserted into the host species' eggs.

The most widely used genetic modifier in plants is the DNA (plasmid) molecule derived from the naturally occurring bacterium Agrobacterium tumefaciens. The desired gene is inserted into the plasmid using recombinant DNA (rDNA) methods. Plant cells attached to tumor cells have a new genetic plasmid, or green parts such as leaves and stems fall off (vessels). Some cells absorb a fraction of the T-DNA plasmid (transferred-DNA). Tumefaciens incorporate the genes needed for one of the plant's chromosomes to produce GM (or mutant) cells. Particle bombardment (gene cannon) is another often used method for switching DNA. The cell is bombarded with small particles lined with DNA molecules in this procedure [24].

A DNA sequence that contains information that determines whether a particular gene/gene exists. DNA is found in all living things (genes). Chromosomes are where genes are found. Genes are heredity items that can be passed down from generation to generation and give instructions for improvement.

Selection of modified plant cells and their regeneration into full plants: Only a small fraction of plant cells absorb the desired gene after mutation, so selective genes that provide antibiotics or weed resistance are often used to increase the number of mutated cells compared to unchanging cells. Resistant genes are inserted into a vector and delivered to plant cells next to genes that provide positive development in this way [25]. Only the transformed cells that have and express the selectable marker gene will survive when the cells are exposed to antibiotics or herbicides. After the plasmids have been removed from the bacterial cells, the typically amplified DNA construct is enzymatically cut out, and it is ready to be inserted into the host species' eggs. Tissue culture procedures are then used to recreate the transformed cells into full blooms. The regulators are told about the marker genes and whether or not they would be present in the advanced GM plant [26].

Detection of the transformation and identification of the inserted DNA fragment: Ensuring that the gene is introduced and inherited is generally required to ensure plant mutations. Tests were performed to determine the number of copies included, if the copies were solid, and whether the installation interfered with other genes, possibly causing unintended consequences [27]. Genetic testing (i.e., messenger RNA and/or protein synthesis, recreational structural tests) were performed to determine if the gene was active. Methods and results are used to determine whether a gene is inserted, the number of copies inserted, whether the copies are damaged, or whether the insertion interferes with the normal characteristics of the plants, and whether the gene is delivered to controls effectively by the engineer [28].

Performance testing of a plant: After mutation, only a small percentage of plant cells absorb a new gene, thus marking genes that provide antiviral or weed-resistant strain are commonly used to identify mutated cells in unchanging cells. Resistant genes are inserted into the vector and supplied to plant cells by the (s) gene that provides the desired traits in this process [29]. While cells are exposed to antibiotics or herbicides, most of the mutated cells have and produce a specific marker element that will survive to tell a myth. Cells have been transformed and regenerated into plants by a process called tissue culture. 
The genetic material of the flag is sent to regulators, along with information on whether or not they will be present at an advanced GM plant [30].

Conduct a risk assessment: A health and environmental risk assessment, as well as a test of the plant's overall performance, are all carried out (Domingo, et al., 2005).

\section{The benefits of GM organisms}

Living organisms that have had their genes altered in some way are known as GMOs (genetically modified organisms). GMOs can be animals or microorganisms, but they're most typically plants, such as maize or potatoes, that have been genetically engineered in the lab to increase the quantity or quality of food they produce [32]. GMO crops provide a variety of advantages, but some organizations are concerned that they may have negative health effects [33].

\section{Increase crop productivity}

Genetically modified seeds can increase agricultural yields or, at the very least, protect the vegetation's yield possible. GMO plants with insect and herbicide resistance can greatly simplify crop management and reduce crop losses, resulting in increased yields [34]. According to Mannion and Morse [35], genetically modified soybean, cotton, and maize varieties produced $20 \%, 15 \%$, and $7 \%$ higher yields than non-genetically modified varieties, respectively.

Farmers across the sector were persuaded that genetically modified seed companies would increase production and profitability. Farmers were expected to follow GM plants, according to GM seed companies, because the improvements they were adopting gave immediate practical advantages for farmers that might be related to increased earnings [36]. Proponents of genetically modified plants have maintained that its use would improve farming's performance, resiliency, and profitability. Furthermore, GM seed firms believe that the acceptance of GM crops reduces the use of insecticides, which has an immediate influence on cropping system sustainability as well as farmer profitability. Some have even proposed that the cultivation of GM vegetation has a halo effect on neighboring non-GM plants by reducing insect pressures in areas where GM crops are often grown [35].

\section{Advantages for the environment}

Environmental benefits of commercialized genetically modified plants are typically associated with reduced pesticide use and tillage. Pesticide reductions can help to increase the conservation of beneficial insects while also protecting non-target species. Reduced tillage aids in the mitigation of soil erosion and pollution, as well as providing indirect environmental benefits such as reduced water contamination from pesticide and fertilizer runoff [37]. It is claimed that developing Bt maize will assist to reduce the usage of chemical pesticides and, to some extent, lessen the production cost They offer more beneficial knowledge for genetics.

The deregulation method for GM crops entails a review of possible environmental concerns as well as unintended consequences that might arise from the insertion of a new gene [38]. Improvements in GM technology will almost certainly allow marginal land to become more effective and may facilitate the remediation of contaminated soils by introducing genes conferring tolerance to abiotic stresses such as drought or inundation, extremes of heat or cold, salinity, aluminum, and heavy metals [39]. As a result, the GM era offers the prospect of boosting agricultural land productivity while reducing the environmental effect.

\section{GMOs are often low-cost}

Farmers can earn a lot of money by using GMOs because they allow them to spend less time on assets. It's also costeffective because these organisms are designed to be pestresistant, which eliminates the need for pesticides and saves money. GMO crops are engineered to grow quickly, allowing farmers to produce the same amount of food with substantially less land, water, and insecticides than traditional crops. Meal makers can potentially reduce the cost of GMO components by stockpiling assets. In other circumstances, ingredients like corn, beets, and soybeans may be reduced by 15 to 30 percent [40]. A DNA sequence that gives information about whether or not a particular feature/trait gene exists. DNA is found in all living organisms (genes). Chromosomes are where genes are found. Genes are pieces of hereditary information that can be passed down from generation to generation and give instructions for improvement.

\section{They increase the value of crops}

The goal of genetically modified organisms is to provide additional vitamins, nutrients, and minerals [41]. For instance, researchers were able to generate a modified variety of African corn that has 2 times the amount of folate as conventional crops, 6 times the amount of vitamin $\mathrm{C}$ as conventional crops, and 169 times the amount of beta-carotene as traditional plants. This is especially useful in places where people are suffering from nutritional inadequacies. The primary rationale for developing GMO plants is that these blossoms provide additional food value, particularly to people who previously lacked essential vitamins and minerals. Plant genes can be transferred to these crops to boost their nutritional value, which is especially significant for hungry individuals. Agricultural yields can be improved without the use of insecticides because GMOs can survive pests and other plant ailments [42].

\section{They are known to lower the cost of meals}

Superior plants and yields almost always suggest lower costs, which is an advantage that may be passed on to customers in the form of lower cost food products. This can be quite advantageous to families that are unable to afford to shop for necessities on a regular basis. This also makes it possible to prevent famine [43].

\section{They produce products that have been found to be safe}

Several GMO crops have been engineered to make them less vulnerable to pests and bugs. Bt-corn, for example, is a GMO crop containing a gene from Bacillus thuringiensis, a soil 
microbe. This gene tells the maize to make a protein that kills a range of pests and bugs, so assisting in the corn's protection [44]. "Instead of being sprayed with a sophisticated pesticide, these plants have an innate 'pesticide,'" Norris adds, meaning that farmers will need to use less pesticide on crops like Btcorn. According to a 2020 study, farmers with GMO plants reduced pesticide consumption by 775.4 million kilos $(8.3 \%)$ between 1996 and 2018. Using fewer pesticides in vegetation may also result in fewer health concerns for those who consume it and less environmental harm. GMOs and other associated items may be found to be safe for human consumption after thorough testing and review. A closer examination reveals that they are even more secure than traditional crops.

\section{The negative effects of genetically modified organisms}

While genetically modified plants can offer numerous benefits in terms of costs and vitamins, some experts are concerned that they may also pose health risks. The extensive use of genetically modified crops has resulted in a host of difficulties relating to food safety, environmental impacts, and socioeconomic concerns [45]. The main drawbacks of gopollination, insect resistance, human fitness, the environment, economics, and productivity are investigated.

\section{They would create plants that would linger in the soil for a long period of time, leaving undesired lasting effects}

GMOs are made by inserting new genetic material into a plant's genome, and this, like bacterial genetic engineering in agricultural ecology, involves the introduction of new genes into plants like maize. These plants were first produced experimentally in the 1980 s in the United States and Canada, and by the mid-1990s, they had become large-scale and industrial. Now, research into the effects of large-scale GMO production has shown a number of problems in ecosystems harboring GMO traces, which might be regarded to have the power to regulate agriculture. For lengthy periods of time, GM plants, in particular, had left undesired or permanent impacts in the soil after they are removed, alerting agricultural regulators. Facts show that their stress lasted for up to six years even in the absence of genetically modified flowers [46].

\section{They may represent a threat to insects that are benefi-} cial to the environment

Some bugs are said to be at risk from genetically modified vegetation since their DNA can be fatal to them. This is a serious problem in terms of beneficial insects that help the ecosystem, such as butterflies, and aren't a serious threat to agriculture [47].

\section{They have the potential to generate extra weeds and en- danger the lives of animals}

Genetically engineered plants have been found to play a role in the transmission of genes to wildflowers and the emergence of weeds. To preserve them under control, scientists are developing new herbicides that are poisonous to many animals that eat GMO crops, including cows, yet are not required for non-GMO weeds. The uptake of certain herbicides that have hazardous effects on particular creatures and the environment, in general, has been shown in tests [48].

\section{They pose a hazard to crop range}

Those who oppose the creation of genetically modified organisms (GMOs) argue that these products would reduce genetic variety. They say that genes from GM plants can spread to organic farm plants, putting agricultural diversity at risk. If crop ranges shrink, it can have a substantial impact on the population dynamics of other species and the environment as a whole. While the possibility of one genetically modified crop wanting to pollinate an already existing non-GM crop is unknown and unlikely, because pass pollination requires certain conditions, a large-scale plantation has the potential to induce GM stress during pollination, increasing the risk. Moving pollination to non-GM flowers produces hybrid strains, which may provide a larger risk of ecological novelty. The introduction of new artificial traces into the atmosphere has the potential to reduce biodiversity through competition [49].

\section{They are suspected of doing shabby business in the} agricultural industry

Research into the effects of mass-producing GM plants has sparked a slew of challenges, particularly those involving GMO strains in ecosystems. These lines, according to scientists, have the potential to harm agriculture [50]. GMOs are certainly a top-notch option when it comes to saving money for our daily meals. However, before using this agricultural era and technique, it is necessary to thoroughly investigate its benefits and drawbacks. Then we can decide if those products are the best alternative for us to generate more profit.

\section{Antibiotic resistance may be exacerbated by GMOs}

GMO scientists usually introduce an additional gene that provides antibiotic resistance to the modified cells when they insert new DNA into plant cells. They can then kill any plant cells that failed to receive the new DNA properly with an antibiotic. Researchers are discovering, however, that these antibiotic-resistant genes don't necessarily go away when you eat GMO foods, and that they could be passed on to sewage systems via your faces. Some researchers are concerned that these genes could be acquired by hazardous bacteria found in sewers or your stomach, which could lead to catastrophic ailments such as staph infections. This indicates that traditional antibiotics may be ineffective against these new high-quality microorganisms. Some specialists disagree, claiming that such a gene switch is unlikely to occur and that people are unlikely to be affected [51].

\section{GMOs have also been linked to allergy responses}

Because GMO foods contain DNA from other animals, it's possible that the new DNA will produce hypersensitivity reactions in people who aren't ordinarily allergic to them. A GMO soybean crop made utilizing DNA from a Brazil nut was found to be harmful to those with nut allergies in one example, and it was unable to be distributed to the general public. GMO 
foods, on the other hand, are subjected to comprehensive allergen testing, so they should pose no greater risk than conventional plants [52-54].

\section{Conclusion}

The introduction of a gene that has a favorable effect is referred to as genetic alteration. The release of GMOs into the environment and the marketing of GM foods has prompted a public debate in many sectors of the industry. The research discussed here suggests that it would be imprudent to dismiss GMO vegetation as a tool for meeting ambitions for sustainable worldwide development as the sector population continues to rise. When employed for goals such as boosting the availability and quality of food and medical treatment, as well as contributing to a cleaner environment, GMOs help humanity. Crops that have been genetically modified are more resilient to abiotic stresses, have a lower reliance on chemical insecticides, have higher effectiveness in mineral utilization by agricultural plants, have a lower post-harvest loss rate, and have a longer dietary cost of food.

\section{Acknowledgment}

I'd want to thank all of my friends who helped me revise my article and provided constructive feedback in order to improve the manuscript's quality.

\section{References}

1. Phillips $T$ (2008) Genetically modified organisms (GMOs): Transgenic crops and recombinant DNA technology. Nature Education 1: 213. Link: https://go.nature.com/3n4OGE1

2. Chandler S, Tanaka Y (2007) Genetic modification in floriculture. Critica Reviews in Plant Sciences 26: 169-197. Link: https://bit.ly/31y1vil

3. Hanley K.A (2011) The double-edged sword: How evolution can make or break a live-attenuated virus vaccine. Evolution: Education and Outreach 4: 635-643. Link: https://bit.ly/3F7eVjo

4. Steinbrecher RA (2015) Genetic Engineering in Plants and the "New Breeding Techniques (NBTs)" Inherent risks and the need to regulate. Econexus Briefing 1-8. Link: https://bit.ly/3JN8W74

5. Noble D (2015) Evolution beyond neo-Darwinism: a new conceptual framework. J Exp Biol 218: 7-13. Link: https://bit.ly/3qZ85Yc

6. Forster BP, Till BJ, Ghanim AMA, Huynh HOA, Burstmayr H, et al. (2014) Accelerated plant breeding. Cab Rev 9: 1-16. Link: https://bit.ly/32X8LVZ

\section{Xu Y (2010) Molecular plant breeding. Cabi. Link: https://bit.ly/32UbnUA}

8. Attfield PV, Bell PJ (2003) Genetic Improvement of Baker's Yeasts. Applied Mycology and Biotechnology. Elsevier 213-240. Link: https://bit.ly/34nSrxX

9. Spicer A, Molnar A (2018) Gene editing of microalgae: scientific progress and regulatory challenges in Europe. Biology 7: 21. Link: https://bit.ly/31y3svy

10. Qaim M (2016) Genetically modified crops and agricultural development. Springer. Link: https://bit.ly/3t5Aajf

11. Simmons MJ, Snustad DP (2006) Principles of genetics. John Wiley \& Sons.

12. Stevens $H$ (2016) Biotechnology and society: an introduction. University of Chicago Press. Link: https://bit.ly/3n6hXow

13. Farkye NY (2004) Cheese technology. International Journal of Dairy Technology 57: 91-98. Link: https://bit.ly/31xJvVF
14. Gaard G (1995) Recombinant bovine growth hormone criticism grows. Alternatives Journal 21: 6-9. Link: https://bit.ly/3n4Rilj

15. Shere J (2013) Renewable: the world-changing power of alternative energy. Macmillan. Link: https://bit.ly/32X3FZZ

16. Halford NG (2012) Genetically modified crops. World Scientific. Link: https://bit.ly/3q1u1Cl

17. Benbrook CM (2016) Trends in glyphosate herbicide use in the United States and globally. Environmental Sciences Europe 28: 1-15. Link: https://bit.ly/3JOHVQF

18. Klümper W, Qaim M (2014) A meta-analysis of the impacts of genetically modified crops. PloS one 9: e111629. Link: https://bit.ly/32XIgQr

19. Barwale RB, Gadwal VR, Zehr U, Zehr B (2004) Prospects for Bt cotton technology in India. Link: https://bit.ly/3q4Mcrs

20. Snow AA, Palma PM (1997) Commercialization of transgenic plants: potential ecological risks. BioScience 47: 86-96. Link: https://bit.ly/34nVYfD

21. Van Harten AM (1998) Mutation breeding: theory and practical applications Cambridge University Press. Link: https://bit.ly/3JRgxSb

22. Schouten HJ, Krens FA, Jacobsen E (2006) Cisgenic plants are similar to traditionally bred plants: international regulations for genetically modified organisms should be altered to exempt cisgenesis. EMBO reports 7: 750-753. Link: https://bit.ly/3F8DTPj

23. Beardmore JA, Porte JS (2003) Genetically modified organisms and aquaculture Food and Agriculture Organization of the United Nations. 989 Link: https://bit.ly/3t5H5Je

24. Zupan JR, Zambryski P (1995) Transfer of T-DNA from Agrobacterium to the plant cell. Plant Physiol 107: 1041-1047. Link: https://bit.ly/3zz7twh

25. Rosellini D (2011) Selectable marker genes from plants: reliability and potential. In Vitro Cellular \& Developmental Biology-Plant 47: 222-233. Link: https://bit.ly/3eWNpuo

26. Nasti RA, Voytas DF (2021) Attaining the promise of plant gene editing at scale. Proceedings of the National Academy of Sciences 118. Link: https://bit.ly/3HFufWg

27. Barampuram S, Zhang ZJ (2011) Recent advances in plant transformation. Methods Mol Biol 1-35.Link: https://bit.ly/3zB0Fy8

28. Yang JH (2008) A study of the intronic promoter of osteoclastic protein tyrosine phosphatase. Loma Linda University.

29. Shrawat AK, Armstrong CL (2018) Development and application of genetic engineering for wheat improvement. CRC Crit Rev Plant Sci s37: 35-421. Link: https://bit.ly/3q25X2

30. Bradford KJ, Van Deynze A, Gutterson N, Parrott W, Strauss SH (2005) Regulating transgenic crops sensibly: lessons from plant breeding biotechnology and genomics. Nat Biotechnol 23: 439-444. Link: https://bit.ly/3HCNqjo

31. Domingo JL, Bordonaba JG (2011) A literature review on the safety assessment of genetically modified plants. Environ Int 37: 734-742. Link: https://bit.ly/3HHL6rn

32. Spring Úo (2011) Genetically modified organisms: A threat for food security and risk for food sovereignty and survival. In coping with global environmental change, disasters and security. Springer, Berlin, Heidelberg 1019-1041. Link: https://bit.ly/31xIU6n

33. Qaim M (2009) The economics of genetically modified crops. Annu Rev Resour Econ 1: 665-694. Link: https://bit.ly/3q0pfWg

34. Van Acker R, Rahman M, Cici SZH (2017) Pros and cons of GMO crop 
farming. In Oxford Research Encyclopedia of Environmental Science. Link: https://bit.ly/3HGtHzo

35. Mannion AM, Morse S (2013) GM crops 1996-2012: A review of agronomic, environmental and socio-economic impacts. Centre for Environmental Strategy, University of Surrey, UK \& Department of Geography and Environmental Science, University of Reading, UK. Link: https://bit.ly/33aPsrY

36. Raman R (2017) The impact of Genetically Modified (GM) crops in modern agriculture: A review. GM Crops Food 8: 195-208. Link: https://bit.ly/3eX3L6e

37. Phipps RH, Park JR (2002) Environmental benefits of genetically modified crops: global and European perspectives on their ability to reduce pesticide use. Journal of Animal and Feed sciences 11: 1-18. Link: https://bit.ly/3G5H2ks

38. Mushunje A, Muchaonyerwa P, Taruvinga A (2011) Smallholder farmers perceptions on $\mathrm{Bt}$ maize and their relative influence towards its adoption: The case of Mqanduli communal area, South Africa. Afr J Agric Res 6: 5918-5923. Link: https://bit.ly/3q1UfF8

39. Duque AS, de Almeida AM, da Silva AB, da Silva JM, Farinha AP, et al. (2013) Abiotic stress responses in plants: unraveling the complexity of genes and networks to survive. Abiotic Stress-Plant Responses and Applications in Agriculture 49-101. Link: https://bit.ly/3f0X3ME

40. Ragavan S (2007) To sow or not to sow: dilemmas in creating new rights in food. Agricultural Biotechnology and Intellectual Property: Seeds of Change 326. Link: https://bit.ly/34id2Uj

41. Hirschi KD (2020) Genetically modified plants: Nutritious, sustainable, yet underrated. J Nutr 150: 2628-2634. Link: https://bit.ly/31CIEV0

42. Bouis HE (2003) Micronutrient fortification of plants through plant breeding: can it improve nutrition in man at low cost? Proc Nutr Soc 62: 403-411. Link: https://bit.ly/3zHF9YU

43. Streeten P (2016) What price food?: Agricultural price-policies in developing countries. Springer.

44. Quarles W (2016) Genetic engineering and pest control. IPM Practitioner 35 1-9. Link: https://bit.ly/3n0E9tt
45. Verma C, Nanda S, Singh RK, Singh RB, Mishra S (2011) A review on impacts of genetically modified food on human health. Open Nutraceuticals $\mathrm{J}$ 4: 3-11. Link: https://bit.ly/34tSLLM

46. Conner AJ, Glare TR, Nap JP (2003) The release of genetically modified crops into the environment: Part II. Overview of ecological risk assessment. Plant $J$ 33: 19-46. Link: https://bit.ly/31y89pc

47. Stewart CN (2004) Genetically modified planet: environmental impacts of genetically engineered plants. Oxford University Press. Link: https://bit. ly/3HJQI9Y

48. Shiva V, Rüesch D, Jafri AH, Dechenne R (2004) Citizens Vote for GMO-Free Food.

49. Engels JMM, Ebert AW, Thormann I, De Vicente MC (2006) Centres of crop diversity and/or origin, genetically modified crops and implications for plant genetic resources conservation. Genet Resour Crop Evol 53: 1675-1688. Link: https://bit.ly/3F4JJI5

50. Buiatti M, Christou P, Pastore G (2013) The application of GMOs in agriculture and in food production for a better nutrition: two different scientific points of view. Genes Nutr 8: 255-270. Link: https://bit.ly/3t3mcyi

51. Read D, Zealand EN (2000) Use of antibiotic resistance marker genes in genetically modified organisms. Wellington: Environmental Risk Management Authority. Link: https://bit.ly/3qPfmtu

52. Lehrer SB, Bannon GA (2005) Risks of allergic reactions to biotech proteins in foods: perception and reality. Allergy 60: 559-564. Link: https://bit.ly/32WUrwS

53. Wesseler J, Scatasta S (2011) The environmental benefits and costs of genetically modified (GM) crops. In Genetically modified food and global welfare. Emerald Group Publishing Limited 10: 173-199. Link: https://bit.ly/3n4k1qz

54. Zhang C, Wohlhueter R, Zhang H (2016) Genetically modified foods: A critical review of their promise and problems. Food Sci Human Wellness 5: 116-123. Link: https://bit.ly/3qZgafo

Discover a bigger Impact and Visibility of your article publication with Peertechz Publications

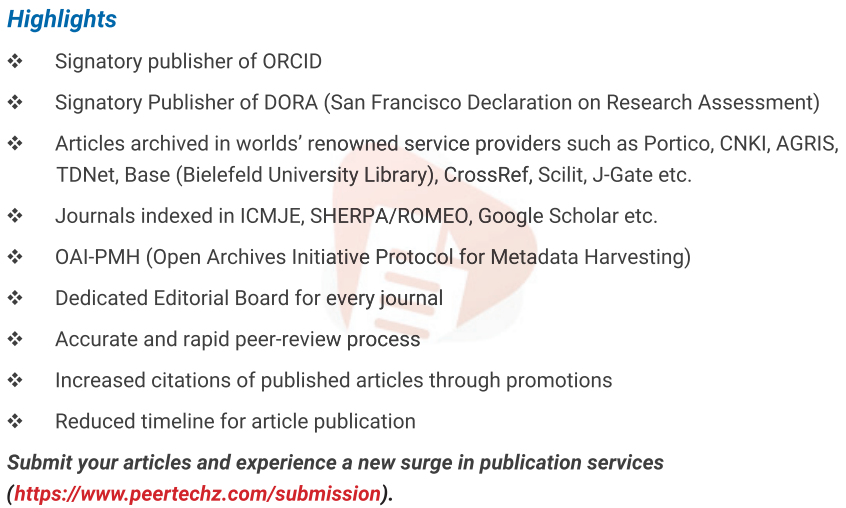

Citation: Yali W (2022) Application of Genetically Modified Organism (GMO) crop technology and its implications in modern agriculture. J Agric Sc Food Technol 8(1): 014-020. DOI: https://dx.doi.org/10.17352/2455-815X.000139 